\title{
Klasifikasi Kecerdasan Majemuk pada Anak Berdasarkan Posting Aktivitas di Media Sosial Menggunakan SentiStrength dan Spearman's Rank Correlation Coefficient
}

\author{
Baihaqi Siregar $^{1}$, Cindy Aprilia ${ }^{1}$, Filia D. Anggaraeni ${ }^{2}$, Ivan Jaya ${ }^{1}$ \\ ${ }^{1}$ Fakultas Ilmu Komputer dan Teknologi dan Informasi, Prodi Teknologi Informasi, Universitas Sumatera Utara, Indonesia \\ ${ }^{2}$ Fakultas Psikologi, Prodi Psikologi, Universitas Sumatera Utara, Indonesia \\ Email: ${ }^{1}$ baihaqi@usu.ac.id
}

\begin{abstract}
Abstrak
Kecerdasan adalah hal-hal yang terkait dengan cerdas, perbuatan mencerdaskan, serta kesempurnaan perkembangan akal budi. Setiap manusia berhak mengembangkan dirinya berdasarkan kecerdasannya. Seorang anak yang jago dalam bermain biola tidak seharusnya membiarkan dirinya merasa dia bodoh disebabkan dia tidak mampu menyelesaikan tugas matematikanya. Oleh karena itu, penulis ingin membuat sistem untuk menentukan bakat anak berdasarkan multiple intelligence (kecerdasan majemuk) yang diukur dari kecenderungan posting mengenai kegiatannya sehari-hari di media sosial dengan menggunakan metode Sentistrength dan Spearman's Correlation Coefficient. Tujuan dari penelitian ini adalah membuat aplikasi media sosial bernama Juicer, yang mampu menentukan bakat seseorang sesuai dengan teori multiple intelligence berdasarkan data berupa postingan user mengenai kegiatannya sehari-hari. User menginputkan kegiatan hariannya dan pendapatnya mengenai kegiatan yang sedang ia jalani. Sistem akan menganalisa data yang diinputkan beropini negatif ataukah positif. Lalu menentukan apakah data yang diinputkan bertipe musical-rhythmic, visual-spatial, verbal-linguistic, logical-mathematical, bodily-kinesthetic, interpersonal, intrapersonal, naturalistic, dan/atau spiritual menggunakan lexicon-based sentiment analysis dengan metode Sentistrength. Setelah dilakukan dalam periode waktu yang cukup panjang, maka sistem akan mensorting data yang telah disimpan. Setelah data diklasifikasikan, akan ditemukan tipe kecerdasan user berdasarkan teori multiple intelligence, sebagai hasil penelitian ini. Hasil korelasi antara data tipe kecerdasan yang didapat melalui sistem dibandingkan dengan data tipe kecerdasan yang didapat melalui cara manual adalah $80 \%$, dan nilai deviasinya adalah 0.09 .
\end{abstract}

Kata Kunci: Multiple Intelligence, Kecerdasan Majemuk, Sentistrength, Lexicon, Sentiment Analysis, Analisis Sentimen

\section{Abstract}

Intelligence are things related to intelligence, intellectual action, and perfect development of the mind. Every human being has the right to develop himself based on intelligence. A child who is good at playing violin shouldn't let himself feel like he is stupid because he is unable to complete his mathematical tasks. Therefore, the author wants to create a system for determining children's talent based on multiple intelligence as measured by the tendency of posts about their daily activities on social media by using the Sentistrength and Spearman's Correlation Coefficient methods. The purpose of this research is to create a social media application called Juicer, which is able to determine one's talent according to multiple intelligence theory based on data in the form of user posts about their daily activities. Users input their daily activities and opinions about the activities that he is currently undergoing. The system will analyze the data entered a negative or positive opinion. Then determine whether the data entered are musical-rhythmic, visual-spatial, verbal-linguistic, logical-mathematical, bodily-kinesthetic, interpersonal, intrapersonal, naturalistic, and / or spiritual-type using lexicon-based sentiment analysis with the Sentistrength method. After a long period of time, the system will sort the data that has been stored. After the data is classified, user intelligence types will be found based on multiple intelligence theory, as a result of this study. The result of the correlation between intelligence type data obtained through the system compared to intelligence type data obtained through the manual method is $80 \%$, and the deviation value is 0.09 .

Keywords: Multiple Intelligence, Compound Intelligence, Sentistrength, Lexicon, Sentiment Analysis, Sentiment Analysis

\section{PENDAHULUAN}

Matthew Kelly (2004), dalam bukunya The Rhythm of Life: Living Everyday with Passion and Purpose mengatakan Albert Einstein pernah berkata "Setiap orang adalah cerdas. Namun, apabila kecerdasan ikan dinilai lewat caranya memanjat pohon, maka dia akan menghabiskan seumur hidup untuk percaya bahwa dirinya bodoh." Melalui kata-katanya Einstein mengimplikasikan bahwa setiap manusia berhak mengembangkan dirinya berdasarkan kemampuannya.

Setiap manusia lahir dengan bakat dan minatnya masing-masing. Pandangan bahwa setiap manusia adalah unik dan berbeda ini mendorong Howard Gardner, seorang pakar psikologi pada tahun 1983 membagi kecerdasan manusia menjadi 8 jenis. Gardner melalui bukunya, Frames of Mind: The Theory of Multiple Intelligences membagi kecerdasan anak menjadi 8 tipe, yaitu musical-rhythmic, visual-spatial, verbal-linguistic, logicalmathematical, bodily-kinesthetic, interpersonal, intrapersonal, dan naturalistic [2]. Lalu, Danah Zohar pada 1997 di bukunya ReWiring the Corporate Brain, menambahkan 1 tipe kecerdasan lagi yaitu spiritual intelligence. Menurut Gardner, tipe kecerdasan seseorang dapat ditemukan dengan mencocokan statement-statement teori dengan kecendrungan kegiatan si pengambil tes sehari-hari. Pengetahuan akan kecerdasan majemuk (multiple intelligence) diri seseorang berguna agar si pengambil tes dapat bekerja, mengeksplorasi, dan mengembangkan diri berdasarkan bidang yang menjadi bakatnya[2].

Kecerdasan Majemuk erat kaitannya dengan Kurikulum Berbasis Kompetensi 2013 yang diberlakukan Kementerian Pendidikan Republik Indonesia. Kurikulum Berbasis Kompetensi 2013 terdiri dari empat dimensi 
yang terkait satu sama lain. Keempat dimensi tersebut adalah sikap spiritual (KI-1), sikap sosial (KI-2), pengetahuan (KI-3), dan keterampilan (KI-4).

Sikap spiritual (KI-1) dapat diteliti dengan ketegori kecerdasan spiritual. Sikap sosial (KI-2) dapat masuk dalam lingkup kecerdasan Interpersonal dan Kecerdasan Intrapersonal. Sedangkan pengetahuan (KI-3), dapat dimasukkan dalam ranah pengembangan kecerdasan linguistik, kecerdasan musikal, dan kecerdasan logicalmathematical. Pada Kompetensi Keterampilan (KI-4), dalam lingkup kecerdasan majemuk dapat dimasukkan dalam ranah pengembangan kecerdasan visual/spatial, bodily-kinesthetic, dan kecerdasan naturalis/Lingkungan.

Berdasarkan survei yang dilakukan oleh BBC News Programme For Children (2016), ditemukan bahwa lebih dari tiga per empat anak menggunakan paling tidak satu media sosial.[9] Rosalie O'Nale menyatakan bahwa walaupun akses terbesar masih dilakukan dari rumah, namun terjadi peningkatan akses yang berasal dari sekolah, telepon genggam ataupun dari tempat yang lain. Penggunaan media sosial dapat digunakan untuk menarik kesimpulan mengenai isi posting dengan menggunakan sentiment analysis.

Pada 2016, Devid Haryalesmana Wahid dan Azhari S.N. Melakukan penelitian Peringkasan Sentimen Esktraktif di Twitter Menggunakan Hybrid TF-IDF dan Cosine Similarity. Penelitian tersebut bertujuan untuk mengekstraksi sentimen masyarakat tentang topik selebriti di Twitter secara otomatis dengan studi kasus Agnes Monica menggunakan kombinasikan metode SentiStrength, Hybrid TF-IDF dan Cosine Similarity[12].

Kumpulan data hasil posting user yang telah ditentukan tipenya dapat diidentifikasi untuk menentukan daftar tipe kecerdasan user dimulai dari yang paling tinggi talentanya sampai yang paling rendah. Korelasi antara data hasil klasifikasi sistem dan data hasil pengumpulan manual dihitung dengan menggunakan Spearman's Rank Correlation Coefficient. Spearman's Rank Correlation Coefficient (Spearman $\rho$ ) ditemukan pada 1904 oleh Charles Spearman, merupakan salah satu statistik pemeringkatan paling awal. Spearman's Rank Correlation Coefficient $(\rho)$ adalah salah satu perhitungan korelasi nonparametic, yang umumnya digunakan untuk menentukan hubungan antara dua set data yang berisi list peringkat.

Oleh karena itu, penulis ingin membuat sistem klasifikasi multiple intelligence pada anak berdasarkan aktivitas posting pada sosial media dengan menggunakan sentistrength dan spearman's rank correlation coefficient.

\section{METODE PENELITIAN}

\subsection{Kecerdasan}

Menurut Kamus Besar Bahasa Indonesia, cerdas adalah pikiran yang tajam dan sempurna perkembangan akal budinya (untuk berpikir, mengerti, dan sebagainya). Sedangkan, kecerdasan adalah hal-hal ynag terkait dengan cerdas, perbuatan mencerdaskan, serta kesempurnaan perkembangan akal budi (seperti kepandaian, ketajaman pikiran). Howard Gardner (1983), menyatakan bahwa kecerdasan adalah kemampuan memecahkan masalah sesuai dengan kondisi yang dihadapi dan kemampuan untuk menghasilkan suatu karya yang berguna bagi lingkungan sesuai minat pribadi masing-masing individu.

\subsection{Kecerdasan Majemuk}

Howard Gardner (1983) menentang pandangan masyarakat umum bahwa individu yang cerdas merupakan seseorang yang memiliki IQ yang tinggi. Menurut Gardner, seseorang yang cerdas adalah seseorang yang mampu membuat suatu karya yang berguna bagi lingkungan sesuai minat pribadi masing-masing individu.[8] Kecerdasan majemuk pada dewasa ini, dibagi menjadi 9 tipe, yaitu:

a. Kecerdasan linguistik (linguistic intelligence) adalah kemampuan untuk memanfaatkan kata-kata dan bahasa untuk mengekspresikan pikiran yang kompleks. (Campbell, et al. 2002)

b. Kecerdasan logika-matematika (logical-mathematical intelligence) adalah kecerdasan untuk memproses dan menganalisis secara berbagai hal secara logis. (Armstrong, 2003).

c. Kecerdasan spasial (spatial intelligence) adalah kemampuan membentuk model mental dari ruang dunia nyata dan mampu memproses model itu menjadi berbagai tujuan (Gardner, 2004).

d. Kecerdasan kinestetik-tubuh (bodily-kinesthetic intelligence) adalah kecerdasan yang memungkinkan seseorang untuk berolahraga, menggerakkan objek dan keterampilan terkait fisik lainnya(Campbell, 2002).

e. Kecerdasan musik (musical intelligence) adalah kecerdasan terkait pada musik dan kepekaan terhadap nada, melodi, dan nada (Hoerr, 2007).

f. Kecerdasan intrapersonal (intrapersonal intelligence) merupakan kemampuan untuk membuat persepsi tentang dirinya sendiri dan menggunakan pengetahuan itu dalam merencanakan dan mengarahkan kehidupan (Campbell, 2002).

g. Kecerdasan interpersonal (interpersonal intelligence) merupakan kemampuan untuk memahami dan berinteraksi dengan orang lain (Campbell, et al. 2002).

h. Kecerdasan naturalis (naturalist intelligence) adalah kemampuan untuk membedakan anggota suatu spesies, mengenali eksistemsi spesies lain dan memetakan hubungan antar spesies, baik secara formal maupun informal. [7]

i. Kecerdasan spiritual/existensial tidak didefinikasan oleh Gardner. Gardner hanya menyatakan bahwa ada kecerdasan selain 8 kecerdasan yang telah dicetuskan sebelumnya, yang disebut sebagai kecerdasan existensial. 
Danah Zonar (2000) mendefinikasikan kecerdasan existensial ini sebagai kecerdasan spiritual. Danah Zonar menyatakan ada 12 prinsip daripada kecerdasan spiritual, yaitu : memiliki kesadaran diri, spontanitas, mampu menjadi pengarah visi dan nilai, holisme, berbelas kasih, menghargai perbedaan, memiliki independensi, memiliki kerendahan hati, memiliki kecenderungan bertanya "Kenapa?", berkemampuan merubah sudut pandang, mampu mengubah kesulitan menjadi keuntungan dan memiliki sense of vocation[6].

\subsection{Analisis Sentimen}

Sentiment Analysis adalah cabang penelitian Text Mining yang bertujuan untuk menentukan apakah teks yang diproses memiliki opini positif, netral, ataupun negatif. Sentiment Analysis mulai berkembang di tahun 2002 dipelopori paper dari B.Pang dan L.Lee. Pada umumnya Sentiment Analysis berdasarkan data yang diprosesnya dapat dibagi menjadi dua tipe yaitu coarse-grained sentiment analysis dan fined-grained sentiment analysis. Coarse-grained sentiment analysis melakukan proses analisis sentimen pada level dokumen. Sedangkan, finedgrained sentiment analysis melakukan proses analisis sentimen pada level kalimat. Penelitian yang penulis lakukan merupakan fined-grained sentiment analysis.

\subsection{SentiStrength}

SentiStrength merupakan program opinion mining yang dikembangkan oleh CyberEmotion. SentiStrength adalah salah satu classifier yang berbasis leksikon. Range value pada SentiStrength adalah -5 sampai dengan -1 dan +1 sampai dengan $+5 .+1$ ataupun -1 menyatakan bahwa sentimen bersifat netral. Semakin value mendekati +5 maka semakin positif sentimen tersebut. Demikian juga sebaliknya semakin mendekati -5 maka semakin negatif sentimen tersebut. Value terbesar (dari masing-masing emotion) dinyatakan sebagai final value. Final value akan diberi tambahan nilai berupa 1 (untuk positif) dan -1 (untuk negatif) guna mencegah emotion bernilai 0 atau kosong. Keputusan akhir diambil berdasarkan :

if positive value > negative value then positive sentiment

if positive value <negative value then negative sentiment

if positive value $=$ negative value then neutral sentiment

\subsection{Klasifikasi tipe kecerdasan anak}

Selama ini untuk menentukan tipe kecerdasan anak digunakan daftar pertanyaan yang seimbang jumlahnya untuk masing-masing tipe. Namun, dalam media sosial tidak dapat ditentukan berapa banyak inputan yang dimasukan setiap orang per tipenya. Oleh karena itu diambil asumsi menggunakan statistika. Dilakukan pengecekan nilai rata-rata setiap tipe dibagi dengan kuantitasnya. Dengan menggunakan rumus :

$$
M I x=\frac{\sum_{i=1}^{n} T i * S i}{n}
$$

$M I=$ Hasil untuk tipe kecerdasan $X$

$X=$ Tipe kecerdasan majemuk yaitu : musical-rhythmic, visual-spatial, verbal-linguistic, logical-mathematical, bodily-kinesthetic, interpersonal, intrapersonal, spiritual, dan naturalistic.

$n=$ Jumlah input untuk tipe kecerdasan $X$

$\mathrm{T}=$ Hasil klasifikasi nilai pernyataan ke-i untuk tipe pernyataan $\mathrm{X}(-5<=\mathrm{A}<=5)$

$S=$ Hasil skor sentimen untuk pertanyaan ke $i$

\subsection{Menghitung korelasi antara tipe kecerdasan hasil survei manual dan hasil klasifikasi sistem}

Korelasi antara data hasil klasifikasi sistem dan data hasil pengumpulan manual dihitung dengan menggunakan Spearman's Rank Correlation Coefficient (Spearman $\rho$ ). Algortima penghitungan Spearman's Rank Correlation Coefficient:

$$
\rho=1-\frac{6 \sum d_{i}^{2}}{n\left(n^{2}-1\right)}
$$

$\rho=$ Spearman's Rank Correlation Coefficient

$\mathrm{di} \quad=\mathrm{RXi}-\mathrm{RYi}$

$\mathrm{RXi}=$ Posisi value tertentu pada list $\mathrm{X}$ dilihat berdasarkan urutan nilai secara ascending

$\mathrm{RYi}=$ Posisi value tertentu pada list Y dilihat berdasarkan urutan nilai secara ascending

$\mathrm{n} \quad=$ Jumlah value pada list $\mathrm{X}$ dan list $\mathrm{Y}$

Nilai korelasi $\rho$ dibandingkan dengan nilai critical value pada tabel Spearman [4]. Apabila $\rho$ lebih besar daripada critical value maka kedua list memiliki korelasi yang cukup besar. Tabel Spearman dapat dicek pada jurnal Critical Values of The Coefficient of Rank Correlation for Testing The Hypothesis of Independence, oleh Glasser dan Winter (1961). 


\subsection{Penelitian Terdahulu}

Delia Robinson Richards, pada 2016, melakukan penelitian di Key School Community di Indianapolis, Briarcliff Rd Elementary School di Briarcliff, New York dan Montgomery Knolls School di Silver Spring, Maryland. Dengan melibatkan petugas sekolah, guru, orang tua, dan murid, Richards menerapkan sistem pengajaran dengan multiple intelligence di ketiga sekolah tersebut. Berdasarkan survei pada para civitas akademika di sekolah-sekolah tersebut didapatkan bahwa multiple intelligence memeberikan dapat yang cukup baik (very good oleh petugas sekolah dan good oleh guru), namun para guru berpendapat masih dibutuhkan waktu lebih untuk mendalami dan menerapkan multiple intelligence di sekolah mereka.

Pada 2015, Enda Esyudha Pratama, and Bambang Riyanto Trilaksono, melakukan penelitian Klasifikasi Topik Keluhan Pelanggan Berdasarkan Tweet dengan Menggunakan Penggabungan Feature Hasil Ekstraksi pada Metode Support Vector Machine (SVM). Mereka mengubah mekanisme proses klasifikasi bentuk dan jenis keluhan serta informasi pelanggan PLN dari manual menjadi automatis melalui dataset Twitter. Dari hasil penelitian menunjukan bahwa SVM mampu melakukan klasifikasi keluhan dengan baik, hal ini dibuktikan dengan akurasi $82,50 \%$ untuk klasifikasi bentuk keluhan dan 86,67\% untuk klasifikasi jenis keluhan. Sedangkan untuk kombinasi penggunaan feature dapat meningkatkan akurasi menjadi $83,33 \%$ untuk bentuk keluhan dan $89,17 \%$ untuk jenis keluhan[10].

Ghulam Asrofi Buntoro melakukan penelitian Analisis Sentimen Calon Gubernur DKI Jakarta 2017 Di Twitter pada tahun 2017. Penelitian tersebut bertujuan untuk membantu riset atas opini masyarakat yang berbedabeda. Media sosial dipilih sebagai bahan penelitian sebab dijaman modern ini semua orang bebas beropini di dunia nyata ataupun maya. Proses klasifikasi tweet menggunakan metode Nä̈ve Bayes Classifier (NBC) dan Support Vector Machine (SVM). Dataset adalah tweet berjumlah 300 buah dengan kata kunci AHY, Ahok, dan Anies ynag berasal dari twitter. Penelitian ini menghasilkan analisis sentimen terhadap calon gubernur DKI Jakarta 2017. Akurasi tertinggi didapat saat menggunakan metode klasifikasi Nä̈ve Bayes Classifier (NBC), dengan nilai ratarata akurasi mencapai $95 \%$, nilai presisi $95 \%$, nilai recall $95 \%$ nilai TP rate $96,8 \%$ dan nilai TN rate $84,6 \%$ [1].

Pada 2016, Devid Haryalesmana Wahid dan Azhari S.N. Melakukan penelitian Peringkasan Sentimen Esktraktif di Twitter Menggunakan Hybrid TF-IDF dan Cosine Similarity. Penelitian tersebut bertujuan untuk mengekstraksi sentimen masyarakat tentang topik selebriti di Twitter secara otomatis dengan studi kasus Agnes Monica menggunakan kombinasikan metode SentiStrength, Hybrid TF-IDF dan Cosine Similarity.

M. Ghiassi, J. Skinner, dan D.Zimbra, pada tahun 2013 melakukan penelitian Twitter brand sentiment analysis: A hybrid system using n-gram analysis and dynamic artificial neural network. Mereka bertujuan untuk mendapatkan gambaran akan pendapat umum terhadap produk tertentu. Dikarenakan mahalnya survei secara manual, maka mereka melakukan sentiment analysis melalui tweet di Twitter. Dengan menggunakan dataset yang berasal dan twitter mereka menganalisis berbagai tweet dari penjuru dunia. Mereka menggunakan teknik hybrid yang merupakan penggabungkan teknik lexicon dan machine language learning, dengan metode $n$-gram analysis dan dynamic artificial neural network dan didapat hasil "lebih dari 80\%"[3].

Putranti, Noviah Dwi, dan Edi Winarko pada tahun 2014 melakukan penelitian option mining pada twitter yaitu analisis sentimen twitter untuk teks berbahasa indonesia. Penelitian yang mereka gunakan menggunakan pendekatan dalam machine learning yang dikenal dengan nama Support Vector Machine dan Maximum Entropy Part of Speech Tagging yang dikhususkan pada dokumen teks berbahasa Indonesia yang unigram. Setelah dianalisis pengecekan tweet secara manual penggunaan POS Tagging menghasilkan akurasi 81,67\% untuk keseluruhan tweet yang menjadi sample(44.006 tweet). Sedangkan berdasarkan emoticon hanya dihasilkan akurasi 43,00\% untuk keseluruhan sample tweet. Dan metode Support Vector Machine yang terdapat dalam sistem dibangun, dengan menggunakan POS Tagging menghasilkan akurasi sebesar 86,81\% dengan waktu proses 1688 detik menggunakan 7 fold cross validation pada tipe kernel Sigmoid[11].

\section{ANALISA DAN PEMBAHASAN}

Beberapa tahapan yang akan dilakukan pada penelitian ini adalah studi literatur, idektifikasi permasalahan, perancangan, implementasi, pengujian, dan penyusunan laporan.

\subsection{Dataset}

\subsubsection{Data Primer}

Data primer yang digunakan dalam penelitian merupakan kumpulan data posting dengan aplikasi media sosial bernama juicer.ga yang berbasis web application. Setiap user memposting sebuah kalimat maka kalimat tersebut akan diproses untuk didapatkan tipe opini dan tipe kecerdasannya dengan menggunakan metode Sentistrength. Pengumpulan data posting dilakukan selama 2 bulan berasal dari 28 siswa Sekolah Menengah Pertama St. Joseph Pemuda Medan, pada tanggal 20 Oktober 2017 sampai dengan tanggal 20 Desember 2017.

\subsubsection{Data Sekunder}


Data sekunder yang digunakan dalam penelitian ini adalah tingkat kecerdasan user yang didapatkan melalui survei secara manual, kamus sentistrength berbahasa Indonesia, kamus emosikon, kamus idiom, kamus Boosterwords, kamus negasi, kamus kata tanya, kamus tipe kecerdasan

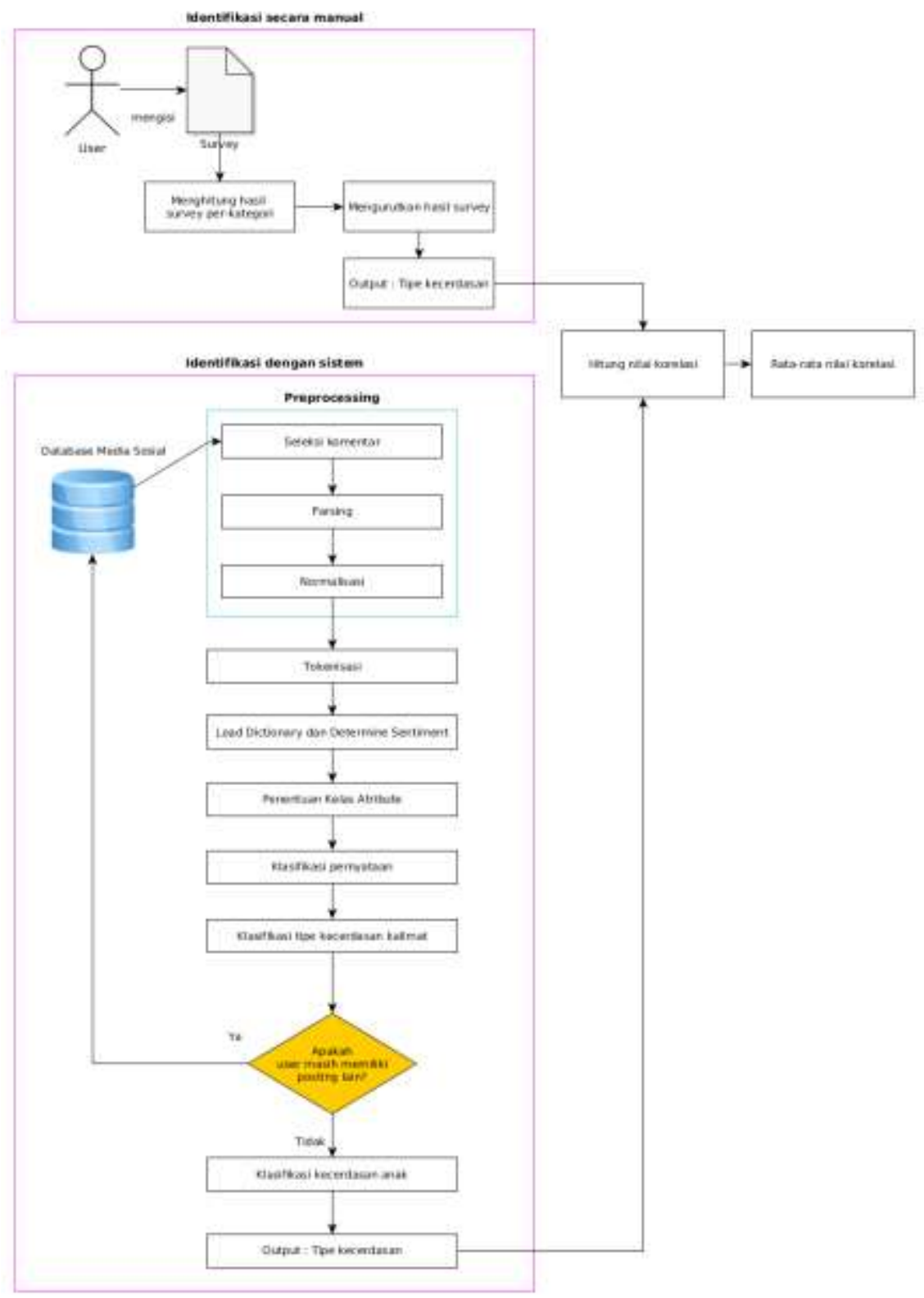

Gambar 1. Arsitektur Umum Sistem

\subsection{Pendeteksian Secara Manual}

Seperti pada gambar 1, user diminta mengisi tes multiple intelligence manual. User menjawab pertanyaanpertanyaan pada survei dengan angka 1 yang didefinisikan sebagai sangat tidak suka, sampai dengan 5 yang didefinisikan sebagai sangat suka[6][13].

\subsubsection{Pendeteksian Dengan Menggunakan Sistem}

Berikut adalah penjelasan arsitektur umum sistem, seperti digambarkan pada gambar 1:

A. Mengambil data

Mengumpulkan data tweet keseharian seorang anak/remaja didapatkan dengan melakukan survey ke sekolah. Target survey diminta untuk mengisi media sosial yang digunakan sebagai pengumpul dataset dengan kegiatan harian mereka dan pendapat mereka terhadap kegiatan tersebut. Data yang diperoleh merupakan data posting mengenai kegatan pada tanggal 20 Oktober 2017 sampai dengan tanggal 20 Desember 2017 di kelas 9-1 SMP St. Yoseph Pemuda Medan yang terdiri dari 29 user. Pada saat user memposting, maka sistem akan memproses post tersebut, yaitu mengidentifikasi tipe kegiatan yang dibicarakan dipost dan apakah posting tersebut beropini positif atau negatif. Misalnya, user memposting sebuah kalimat yang berisi 'Permainan voli pada hari ini sangat 
menyenangkan. Saya suka sekali bermain voli'. Kalimat tersebut akan diterima oleh sistem dan dikirimkan untuk diproses untuk diambil skor sentimennya.

B. Preprocessing

- Seleksi komentar

Seleksi komentar dilakukan secara manual.

- Parsing

Parsing adalah proses memecah dokumen menjadi penggalan kata dengan melakukan analisa terhadap kalimat (Putro, 2011). Misalnya, kalimat 'Permainan voli pada hari ini sangat menyenangkan. Saya suka sekali bermain voli'. Akan dibagi menjadi 2 buah array of sentences yaitu 'Permainan voli pada hari ini sangat menyenangkan.' dan 'Saya suka sekali bermain voli'

- Normalisasi Kalimat

Normalisasi kalimat adalah menormalkan kalimat tidak baku menjadi baku sehingga dapat dikenali sebagai bahasa yang sesuai dengan KBBI. (Adiyasa, 2013), Langkah menormalisasi kalimat adalah:

a. Membuat kalimat menjadi all lower case

Misalnya kalimat 'Permainan voli pada hari ini sangat menyenangkan.' akan diubah menjadi 'permainan voli pada hari ini sangat menyenangkan'

b. Menghapus character yang berulang lebih dari dua kali

Misalnya, kata 'aku lapaaaaar' akan diubah menjadi 'aku lapar'.

c. Mengubah kata plural menjadi singular

Misalnya, kata 'hari ini banyak sekali truk-truk besar di jalanan' akan diubah menjadi 'hari ini banyak sekali truk besar di jalanan'.

d. Normalisasi kata

Pada tabel I. tercantum daftar kata-kata bahasa Indonesia yang umumnya mengalami penyingkatan.

Kata-kata yang mengalami penyingkatan tidak baku dikembalikan menjadi baku dengan normalisasi. Misalnya, 'Saya soeka sekali bermain voli'. Akan diubah menjadi 'saya suka sekali main voli'.

Tabel 1. Tabel Normalisasi Kata

\begin{tabular}{ll}
\hline \multicolumn{1}{c}{ Tidak Normal } & \multicolumn{1}{c}{ Normal } \\
\hline Akhiran -ny & Akhiran -nya \\
Akhiran $-\mathrm{nk}$ & Akhiran -ng \\
Akhiran $-\mathrm{x}$ & Akhiran -nya \\
Akhiran $-\mathrm{z}$ & Akhiran $-\mathrm{s}$ \\
Akhiran -dh & Akhiran $-\mathrm{t}$ \\
Kata berulang: sama2 & Kata berulang: sama-sama \\
Ejaan: oe & Huruf: $\mathrm{u}$ \\
Ejaan: dj & Huruf: $\mathrm{j}$ \\
\hline
\end{tabular}

C. Tokenisasi

Kalimat yang telah dinormalisasi akan dipecah menjadi token-token dengan delimiter yaitu spasi. Token yang digunakan dalam penelitian ini adalah 1-gram yaitu dari satu kata setiap satu token, contohnya: 'Tari Saman Aceh' menjadi 'Tari', 'Saman', 'Aceh'. Misalnya, kata 'saya suka sekali main voli' akan diubah menjadi array of words, yaitu 'saya', 'suka', 'sekali', 'bermain', 'voli'.

D. Load Dictionary dan Determine Sentiment

Banyak kamus yang tersedia untuk menentukan nilai bobot nilai suatu kata. Dalam penelitian ini untuk klasifikasi pernyataan digunakan kamus yang disusun oleh Devid Haryalesmana Wahid dan Azhari SN. Sedangkan untuk pengklasifikasian tipe akan digunakan kamus buatan sendiri dengan penilaian yang berasal dari pakar.

E. Penentuan Kelas Atribute

Kelas atribute pada penelitian ini terbagi menjadi 2 jenis, yaitu pada penentuan suka dan tidak, serta pada penentuan tipe kegiatan yang diceritakan. Penentuan suka dan tidak terbagi menjadi positif, negatif dan netral. Sedangkan penetuan tipe kegiatan terbagi menjadi musical-rhythmic, visual-spatial, verbal-linguistic, logical-mathematical, bodily-kinesthetic, interpersonal, intrapersonal, naturalistic, dan spiritual. Akan diberikan atribut mengenai sentimen kesukaan yang ditandai dengan [], dan atribut mengenai multiple intelligence yang akan ditandai dengan \{\} . Misalnya, array of words 'saya', 'suka', 'sekali', 'bermain', 'voli'. Akan diberikan atribut menjadi 'saya', 'suka' $[+4]$, 'sekali' $[+(4+1)]$, 'main', voli\{kinestik:3.54, matematis:0.42, interpersonal:0.63, intrapersonal:0.42\}.

F. Klasifikasi pernyataan

Pernyataan diklasifikasikan sebagai netral apabila kalimat merupakan kalimat tanya, ataupun pada saat nilai positif dan negatif sebanding. Apabila kalimat, bukanlah kalimat netral, maka dilihat nilai absolut yang terbesar apakah positif atau negatif. Misalnya pada kalimat 'saya suka sekali main voli', yang telah diproses menjadi array of words dengan atribut 'saya', 'suka' $[+4]$, 'sekali' $[+(4+1)]$, 'main', voli\{kinestik:3.54, 
matematis:0.42, interpersonal:0.63, intrapersonal:0.42\}. Maka didapatkan nilai tertinggi dari opini kalimat tersebut adalah +5 . [12]

G. Penentuan tipe kecerdasan kalimat

Nilai terbesar dari setiap tipe kecerdasan yang telah diatributkan pada kalimat menjadi tipe kecerdasan kalimat. Misalnya pada kalimat 'saya suka sekali main voli', yang telah diproses menjadi array of words dengan atribut 'saya', 'suka'[+4], 'sekali' $[+(4+1)]$, 'main', voli\{kinestik:3.54, matematis:0.42, interpersonal:0.63, intrapersonal:0.42\}. Maka didapatkan nilai tertinggi dari setiap tipe kecerdasan pada kalimat tersebut adalah tersebut adalah kinestik 3.54, matematis 0.42 , interpersonal 0.63 , dan intrapersonal adalah 0.42 .

H. Klasifikasi tipe kecerdasan anak

Kecerdasan seseorang dapat dibagi menjadi 9 tipe yaitu : musical-rhythmic, visual-spatial, verbal-linguistic, logical-mathematical, bodily-kinesthetic, interpersonal, intrapersonal, spiritual, dan naturalistic. Dalam penelitian ini hanya dimunculkan tipe : musical-rhythmic, visual-spatial, verbal-linguistic, logicalmathematical, bodily-kinesthetic, dan naturalistic.

Selama ini untuk menentukan tipe kecerdasan anak digunakan daftar pertanyaan yang seimbang jumlahnya untuk masing-masing tipe. Namun, dalam media sosial tidak dapat ditentukan berapa banyak inputan yang dimasukan setiap orang per tipenya. Oleh karena itu diambil asumsi menggunakan statistika.

Dilakukan pengecekan nilai rata-rata setiap tipe dibagi dengan kuantitasnya. Dengan menggunakan rumus :

$$
M I x=\frac{\sum_{i=1}^{n} T i * S i}{n}
$$

MI = Hasil untuk tipe kecerdasan X

$\mathrm{X}$ = Tipe kecerdasan majemuk yaitu : musical-rhythmic, visual-spatial, verbal-linguistic, logical-mathematical, bodily-kinesthetic, interpersonal, intrapersonal, spiritual, dan naturalistic.

$\mathrm{n}=$ Jumlah input untuk tipe kecerdasan $\mathrm{X}$

$\mathrm{T}=$ Hasil klasifikasi nilai pernyataan ke-i untuk tipe pernyataan $\mathrm{X}(-5<=\mathrm{A}<=5)$

$\mathrm{S}=$ Hasil skor sentimen untuk pertanyaan ke $\mathrm{i}$

Lalu diurutkan berdasarkan tipe dengan hasil yang tertinggi hingga yang terendah, Tipe tertinggi merupakan tipe yang paling diminati si anak sedangkan nilai yang terendah menyatakan tipe yang paling tidak diminati si anak.

Misalnya ada user X yang memiliki 8 posting dengan nilai masing-masing seperti pada tabel II. Maka skor masing-masing tipe kecerdasan akan dikalikan dengan nilai. Lalu diambil rata-ratanya sebagai hasil akhir seperti ditampilkan pada tabel III.

Tabel 2. Contoh Nilai Dari User X

\begin{tabular}{ccccccccccc}
\hline $\begin{array}{c}\text { ID } \\
\text { Posti } \\
\text { ng }\end{array}$ & $\begin{array}{c}\text { interpers } \\
\text { onal }\end{array}$ & $\begin{array}{c}\text { intrapers } \\
\text { onal }\end{array}$ & $\begin{array}{c}\text { Kines } \\
\text { tik }\end{array}$ & $\begin{array}{c}\text { Linguis } \\
\text { tik }\end{array}$ & $\begin{array}{c}\text { Matem } \\
\text { atis }\end{array}$ & $\begin{array}{c}\text { Musi } \\
\text { kal }\end{array}$ & $\begin{array}{c}\text { Naturali } \\
\text { stik }\end{array}$ & $\begin{array}{c}\text { Spirit } \\
\text { ual }\end{array}$ & $\begin{array}{c}\text { Visu } \\
\text { al }\end{array}$ & $\begin{array}{c}\text { Nil } \\
\text { ai }\end{array}$ \\
\hline 1 & 0.1 & 1.1 & 0 & 0 & 3.7 & 0 & 0 & 0 & 0 & +5 \\
2 & 0 & 0 & 0 & 0 & 0 & 0 & 4.3 & 0 & 2.7 & +3 \\
3 & 0 & 0 & 4.8 & 0 & 0 & 0 & 2.7 & 0 & 1.4 & -4 \\
4 & 0 & 0 & 0 & 0 & 3.6 & 0 & 0 & 0 & 1.7 & +2 \\
5 & 0 & 2.1 & 0 & 0 & 0 & 0 & 0 & 3.6 & 0 & +1 \\
6 & 0 & 0 & 0 & 4.3 & 0 & 0 & 0 & 0 & 2.1 & 0 \\
7 & 0.3 & 0 & 0 & 0 & 3.9 & 0 & 0 & 0 & 0 & -1 \\
8 & 0.5 & 0 & 4.7 & 0 & 0.2 & 3.7 & 0 & 0 & 0 & -2 \\
\hline
\end{tabular}

Tabel 3. Contoh Hasil Proses User X

\begin{tabular}{llllllllll}
\hline $\begin{array}{l}\text { ID } \\
\text { Posting }\end{array}$ & Interpersonal & Intrapersonal & Kinestik & Linguistik & Matematis & Musikal & Naturalistik & Spiritual & Visual \\
\hline 1 & 0.5 & 5.5 & 0 & 0 & 18.5 & 0 & 0 & 0 & 0 \\
2 & 0 & 0 & 0 & 0 & 0 & 0 & 12.9 & 0 & 8.1 \\
3 & 0 & 0 & -19.2 & 0 & 0 & 0 & -10.8 & 0 & -5.6 \\
4 & 0 & 0 & 0 & 0 & 7.2 & 0 & 0 & 0 & 3.4 \\
5 & 0 & 2.1 & 0 & 0 & 0 & 0 & 0 & 3.6 & 0 \\
6 & 0 & 0 & 0 & 0 & 0 & 0 & 0 & 0 & 0 \\
7 & -0.3 & 0 & 0 & 0 & -3.9 & 0 & 0 & 0 & 0 \\
8 & -1.0 & 0 & -9.4 & 0 & -0.4 & -7.4 & 0 & 0 & 0 \\
Rata- & -0.10 & 0.95 & -3.58 & 0.00 & 2.68 & -0.93 & 0.26 & 0.45 & 0.74 \\
rata & & & & & & & & &
\end{tabular}


I. Output

Output berupa hasil klasifikasi kecerdasan user dilihat dari hasil analisis sentimen postingannya. Terdiri dari grafik batang yang menunjukan seberapa tingkat kecerdasannya pada bidang musical-rhythmic, visualspatial, verbal-linguistic, logical-mathematical, bodily-kinesthetic, dan naturalistic. Dan penjelasan mengenai tipe kecerdasan tersebut dan cara mengembangkannya. Misalnya, ada data berisi rata-rata tipe kecerdasan seperti berikut : interpersonal (-0.1), intrapersonal (0.95), kinestik (-3.58), linguistik (0), matematis (2.68), musikal (-0.93), naturalistik (0.26), spiritual (0.45), visual (0.74). Maka data tersebut akan diurutkan dari yang terbesar menjadi : matematis (2.68), intrapersonal (0.95), visual (0.74), spiritual (0.45), naturalistik (0.26), linguistik (0), interpersonal (-0.1), musikal (-0.93), kinestik (-3.58). Sehingga didapatkan tipe kecerdasan User $\mathrm{X}$ dari yang paling memungkinkan adalah matematis, intrapersonal visual, spiritual, naturalistik, linguistik, interpersonal, musikal, dan terakhir kinestik.

\subsection{Menghitung Korelasi Antara Hasil Pendeteksian Manual Dan Pendeteksian Melalui Sistem}

Korelasi antara hasil pendeteksian manual dan pendeteksian melalui sistem dihitung dengan menggunakan Spearman's Rank Correlation Coefficient.

$$
\rho=1-\frac{6 \sum d_{i}^{2}}{n\left(n^{2}-1\right)}
$$

\section{$\rho \quad=$ Spearman's Rank Correlation Coefficient}

$\mathrm{di} \quad=\mathrm{RXi}-\mathrm{RYi}$

$\mathrm{RXi}=$ Posisi value tertentu pada list $\mathrm{X}$ dilihat berdasarkan urutan nilai secara ascending

$\mathrm{RYi}=$ Posisi value tertentu pada list Y dilihat berdasarkan urutan nilai secara ascending

$\mathrm{n} \quad=$ Jumlah value pada list $\mathrm{X}$ dan list $\mathrm{Y}$

Nilai korelasi $\rho$ dibandingkan dengan nilai critical value pada tabel Spearman (Tabel 2.1). Apabila $\rho$ lebih besar daripada critical value maka kedua list memiliki korelasi yang cukup besar.

\section{IMPLEMENTASI}

\subsection{Pengujian}

Pada tahap implementasi aplikasi, pengambilan posting menggunakan bahasa pemrograman PHP5 dan HTML5. Sedangkan pada bagian pemrosesan tipe kecerdasan dan penentuan nilai korelasi digunakan bahasa pemrograman Python3.

\subsection{Contoh Hasil Pengujian}

User dengan hasil seperti grafik pada gambar 1 dari tipe kecerdasan dimana dia paling berbakat sampai yang mana dia kurang berminat secara berurutan berdasarkan gambar adalah : Matematis, Kinestik, Visual, Musikal, Naturalistik, Linguistk

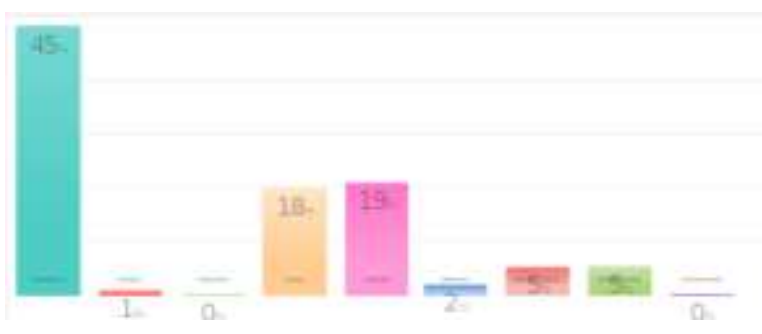

Gambar 2. Grafik Hasil Tipe Kecerdasan User X

\subsection{Korelasi Antara Data Hasil Sistem Dengan Data Manual}

Hasil korelasi antara data tipe kecerdasan yang didapat melalui sistem dibandingkan dengan data tipe kecerdasan yang didapat melalui cara manual adalah $80 \%$, dan nilai deviasinya adalah 0.09 .

\section{KESIMPULAN}

Berdasarkan pengujian dan penelitian yang dilakukan pada posting mengenai kegiatan sehari-hari di juicer.ga, kesimpulan yang dapat diambil yaitu:

1. Output dari penelitian berupa tipe kecerdasan menurut teori multiple intelligence, dengan tipe kecerdasan, yaitu : musical-rhythmic, visual-spatial, verbal-linguistic, logical-mathematical, bodily-kinesthetic, dan naturalistic. 
2. Untuk mendapatkan tipe kecerdasan user berdasarkan posting yang telah diinputkan adalah dengan menganalisis parameter-parameter yang berhubungan dengan sentiment analysis pada kalimat posting yaitu kata-kata yang menyatakan sentimen kesukaan dan kata-kata yang terkait dengan aktivitas.

3. Korelasinya system dengan hasil manual untuk mendapat tingkat akurasi penelitian ini dengan menggunakan metode Spearman's Rank Correlation Coefficient. Hasil korelasinya adalah 80\% dengan standar deviasi 0.09

\section{REFERENCES}

[1] Buntoro, Ghulam Asrofi. 2017. Analisis Sentimen Calon Gubernur DKI Jakarta 2017 di Twitter. INTEGER: Journal of Information Technology 2579-566X 1:32-41.

[2] Gardner H. 2011. Frames of Mind: The Theory of Multiple Intelligences. Ed ke-2011. New York (US): Basic Books.

[3] Ghiassi M, Skinner J, Zimbra D. 2013. Twitter brand sentiment analysis: A hybrid system using n-gram analysis and dynamic artificial neural network. Expert Systems with Applications. 40(16):6266-6282.

[4] Glasser, G.J. \& Winter, R.F. 1961. Critical values of the coefficient of rank correlation for testing the hypothesis of independance. Biometrika 48, pp. 444-448.

[5] Marshall DZ\&I. 2000. SQ: Connecting with Our Spiritual Intelligence. Ed ke-1. New York (US): Bloomsbury.

[6] McKenzie, Walter. 1999. Multiple intelligences inventory. http://surfaquarium.com/MI/inventory.htm (diakses 15 Desember 2017)

[7] Minsih. 2013. Pengembangan Kecerdasan Majemuk pada Implementasi Kurikulum 2013. The 1st Summit Meeting on Education the End of the Year 2013 Seminar Nasional: Refleksi dan Realisasi Kurikulum 2013; pp. 278-286.

[8] Musfiroh, Tadkiroatun. 2014. Pengembangan Kecerdasan Majemuk. Hakikat Kecerdasan Majemuk (Multiple Intelligences), pp. 1-60.

[9] Newsround survey reveals majority of 10 to 12 year-olds are on social media. 2016. http://www.bbc.co.uk/mediacentre/latestnews/2016/newsround-survey-social-media, 9 Februari 2016 (diakses 2 Mei 2017).

[10] Pratama EE, Trilaksono BR. 2015. Klasifikasi topik keluhan pelanggan berdasarkan tweet dengan menggunakan penggabungan feature hasil ekstraksi pada metode support vector machine (SVM). Jurnal Edukasi dan Penelitian Informatika (JEPIN). 1(2):53-59.

[11] Putranti ND, Winarko E. 2014. Analisis sentimen twitter untuk teks berbahasa indonesia dengan maximum entropy dan support vector machine. IJCCS-Indonesian Journal of Computing and Cybernetics Systems 8.1. 8.1:91-100.

[12] Wahid DH, SN A. 2016. Peringkasan sentimen esktraktif di twitter menggunakan hybrid TF-IDF dan cosine similarity. IJCCS (Indonesian Journal of Computing and Cybernetics Systems). 10(2):207.

[13] Winarto P. 2010. Maximizing Your Talent (Menemukan \& Memaksimalkan Potensi Diri Anda). Medan (ID): PT BPK Gunung Mulia. 